\title{
https://doi.org/10.46813/2020-130-019 \\ INFLUENCE OF THE PHOTODIODE SPECTRAL SENSITIVITY ON THE TEMPERATURE ESTIMATION BY SXR USING THIN FILTERING FOILS IN URAGAN-3M
}

\author{
M.B. Dreval ${ }^{1}$, O.V. Turianska ${ }^{1,2}$, A.S. Pahur ${ }^{1,3}$ \\ ${ }^{1}$ Institute of Plasma Physics NSC “Kharkov Institute of Physics and Technology”, Kharkiv, Ukraine; \\ ${ }^{2}$ CELIA Université Bordeaux, Talence, France; \\ ${ }^{3}$ V.N. Karazin Kharkiv National University, Kharkiv, Ukraine \\ E-mail: mdreval@kipt.kharkov.ua
}

Soft X-ray (SXR) diagnostics is routinely used in Uragan-3M (U-3M) torsatron. One of the SXR diagnostic applications is based on the plasma temperature estimation. The ratio of SXR signals passed through two different foils depends only on the plasma temperature and can be used for its estimation. An influence of spectral sensitivity of the photodiode on the two foils temperature estimations technique is considered in present work numerically. The influence is negligible in the case of the flat sensitivity in the energy range $5 \ldots .500 \mathrm{eV}$ in the case of thin $1.5 / 2.25 \mu \mathrm{m} \mathrm{Al}$ foils. In the opposite case of very low spectral sensitivity in $5 \ldots .500 \mathrm{eV}$ range and its increase at the $1 \mathrm{keV}$ range the signals ratio can be very high. This result can explain high signals ratio experimentally observed in Uragan-3M stellarator, where photodiodes with unknown spectral sensitivity were used.

PACS: 52.55.Hc; 52.70.La

\section{INTRODUCTION}

The Soft X-ray diagnostics is one of the most important basic diagnostics to study the magnetically confined plasma in stellarators, tokamak, reverse field pinch, etc [1-3]. The SXR diagnostics is mainly used for magnetohydrodynamic studies and impurity accumulation studies. One of the SXR diagnostic applications in small fusion devises, where more sophisticated diagnostics are missing, is the estimation of the electron temperature $\left(T_{e}\right)$ of the plasma via two foils technique. This temperature evaluation method based on a strong dependence of the continuum Bremsstrahlung SXR radiation on the electron temperature. A broadband light emission from plasma is filtered by fin beryllium or aluminum foil in order to separate SXR emission from visible part of the plasma emission. The SXR energy spectrum, passed through the foil, depends on the foil thickness and material. The two foils technique used for the estimation of the electron temperature is based on the ratio $R$ of the SXR brightness passed through different foils. Thin foils are used in small fusion device Uragan-3M (U-3M) due to low level of the SXR emission from low density and low temperature plasma. Application of the two foils technique in rather thin foils case is described in Ref. [4]. According to this work contribution of the spectral lines emission to the SXR emission can be ignored. We are considering Bremsstrahlung emission only in present work. The Bremsstrahlung formula has the following form:

$$
\frac{d W}{d E} \propto n_{e}^{2}(r) Z_{e f f}(r) T_{e}^{-0.5}(r) e^{-\frac{E}{T_{e}(r)}},
$$

where $d W$ is the radiation power emitted in the photon energy interval $d E$ and $n_{e}, Z_{e f f}$, and $T_{e}$ are electron density, effective plasma charge and electron temperature, respectively. The SXR emission is filtered by two aluminum or beryllium foils with different thicknesses. The foil material and thickness define the energy absorption threshold. In the case of higher SXR energy, the emission is passed through thicker foil. Thus, the ratio of SXR emission measured by two different foils contains information about emission energy the electron temperature consequently. The SXR intensity in the detector for the Maxwellian plasma is:

$$
I \propto \int_{l} \frac{n_{e}^{2}(l)}{\sqrt{T_{e}(l)}} Z_{e f f} \int_{E} \xi(E) d E d l,
$$

where is the first integral along the line of sight path $l$ represent the integral nature of the SXR emission from the plasma and the second integral represent the integration of local emission and absorption of the SXR emission by the foil versus energy. The function $\xi$ is:

$$
\xi(E)=\exp \left[-\frac{E}{T_{e}(l)}\right] \cdot \exp \left[-\frac{\mu}{\rho}(E) \rho \cdot t\right],
$$

where $\mu / \rho$ is the mass energy absorption coefficients of the foil, $t$ is the foil thickness. Generally, the problem is complex and needs inversion due to the first integral another line of sight. According to experimental measurements $[5,6]$ the shape of SXR profile have a very peaked form in $\mathrm{U}-3 \mathrm{M}$. The major contribution to the line-integrated SXR signal comes from most central part of the SXR line-of-sight. The contribution from the plasma periphery can be neglected. In this case, the SXR signal in the detector is expressed as follow:

$$
I \approx Z_{\text {eff }} \frac{n_{e}^{2}\left(l_{0}\right)}{\sqrt{T_{e}}\left(l_{0}\right)} \int_{E} \xi(E) d E .
$$

The integral part of this formula depends on just the central electron temperature. Concerning the ratio of SXR signals passed through two foils they depend only on the central temperature:

$$
R=\frac{I_{1}}{I_{2}}=R\left(T_{e}\right)
$$


This formula supports the two foils technique applicability. Due to the complex $\mu(E) / \rho$ dependence the ratio $R$ of the signals is usually calculated numerically. Previous numerical calculations [7] shows that the ratio $R$ is weakly depend on the plasma temperature in the case of the 1.5 and $2.25 \mu \mathrm{m}$ aluminum foil. Thicker second foil is strongly required for viewable dependence of the ratio $R$ on the plasma temperature. However high $R$ was observed experimentally in U-3M in these thin foils case [8]. One of the possible reasons for the discrepancy is based on the possible influence of the spectral sensitivity of the photodiodes, which are used in the SXR measurement systems. Real dependence of the sensitivity on the SXR wavelength can substantially modify the ratio of the signal, especially in the case of the low difference between thicknesses of the foil. According to the Ref. [9] spectral sensitivity of the SXR photodiode introduces additional term in Eq. (3) as follows:

$$
\xi(E)=\exp \left[-\frac{E}{T_{e}(l)}\right] \cdot \exp \left[-\frac{\mu}{\rho}(E) \rho \cdot t\right] \cdot F(E),
$$

where $F$ is a spectral sensitivity of the photodiode. This influence is negligible if $F$ is constant in the $5 \ldots .500 \mathrm{eV}$ energy range [9]. Old photodiodes with unknown and undocumented spectral response $F$ was used in U-3M experiments [8]. The $F$ function of these diodes can be different to the Ref. [9] estimations. Different shape of the spectral response function $F$ is used in present work. The $F$ functions with very low spectral sensitivity in $5 \ldots .500 \mathrm{eV}$ range with strong increase in $1 \mathrm{keV}$ range is used in the present work.

\section{NUMERICAL MODELING OF SIGNALS RATIO $R$ VERSUS SPECTRAL SENSTIFIVITY $\boldsymbol{F}$}

The various form of decayed spectral sensitivity function was used in our simulation following [9]. For calculations, we used the spectral sensitivity of the photodiode in the form:

$$
F(E)=\exp \left[-\left(\frac{E}{E_{\lim }}\right)^{\alpha}\right]
$$

In this form the $E_{\lim }$ value defines start of the spectral sensitivity decay and $\alpha$ value define the decay speed. Set of modeling functions $F$ and corresponding signals SXR ratios $R$ shown in Figs. 1, 2 correspondently by same colors.

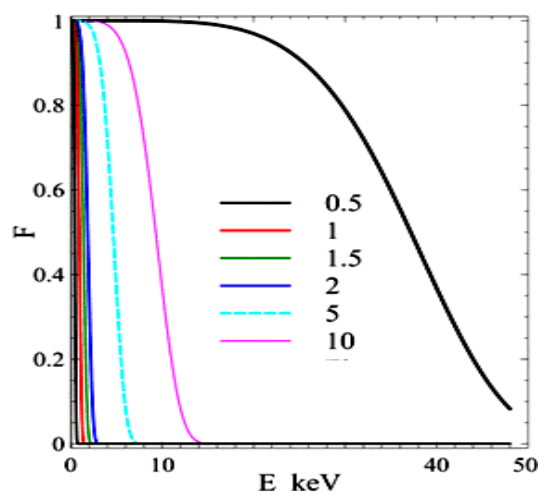

Fig. 1. Modeling F functions described by Eq (7) for $\alpha=5$, and set $E_{\text {lim }}$ as it is shown in the legend
The ratio of signals passed through the 1.5 and $2.25 \mu \mathrm{m}$ aluminum filters are weakly depends on the plasma temperature (see Fig. 2). More detailed analysis of this type of $F$ [9] shows, that a variation of the decayed function $F$ cannot increase the ratio $R$ up to the experimentally observed values. Set of rising modeling functions is described as:

$$
F(E)=\operatorname{Sin}(\beta \pi+\sigma E)+1 .
$$

These modeling functions are shown in Fig. 3.

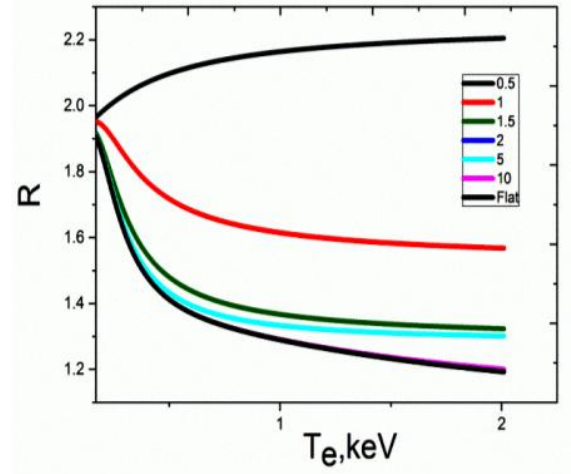

Fig. 2. Calculated R-function for Al 1.5 / $2.25 \mu \mathrm{m}$ case and $F$-functions from Fig. 1

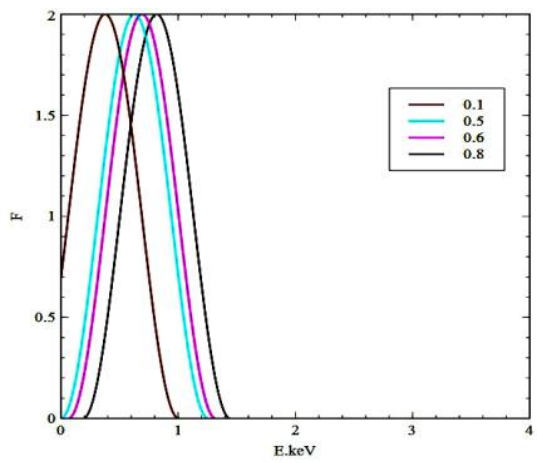

Fig. 3. Modeling F functions, values of $\beta$ are shown in the legend

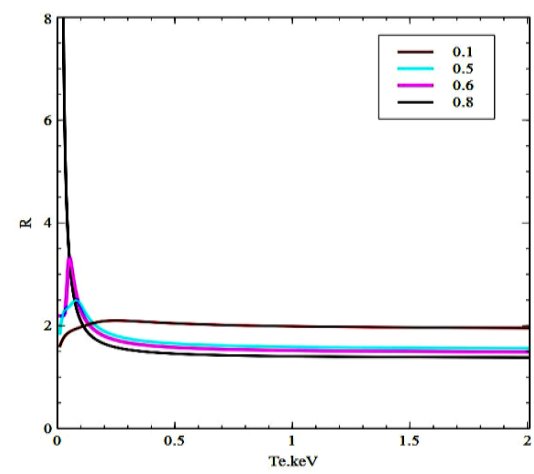

Fig. 4. R function for Al $1.5 / 2.25 \mu \mathrm{m}$ and $\mathrm{F}$ functions from Fig. 3

Very high signals ratio $R$ can be observed in the case of very low spectral sensitivity in the energy range of $5 \ldots 250 \mathrm{eV}(\beta=0.8$ case), as shown in Fig. 4 . The dependence of the photodiode senstitivity in this range is crucial for the temperature estimation in the thin $(1.5 / 2.25 \mu \mathrm{m}) A l$ foils case. This type of $F$ function can explain high SXR signals ratio observed in U-3M even in the case of pure Bremsstrahlung radiation from Maxwellian plasma. 


\section{SUMMARY AND CONCLUSIONS}

The ratio of SXR signals passed through two different foils depends only on the plasma temperature and can be used for its estimation. An influence of spectral sensitivity of the photodiode on the two foils temperature estimations technique is numerically evaluated in present work. Our calculations for the 1.5/2.25 $\mu \mathrm{m} A l$ foils and pure Bremsstrahlung emission from the Maxwellian plasma show that:

a) The influence of spectral sensitivity is negligible if the spectral sensitivity is weakly depends on SXR energy in the energy range of $5 \ldots .500 \mathrm{eV}$.

b) Strong contribution form the spectral sensitivity is observed if it is low in the $5 \ldots .500 \mathrm{eV}$ range and drastically increases in the $1 \mathrm{keV}$ range.

These results can explain the high SXR signals ratio, which is observed experimentally in URAGAN-3M. The unknown and undocumented spectral sensitivity function of old photodiodes can cause these experimental observations.

\section{ACKNOWLEDGEMENTS}

This work has been supported by National Academy Science of Ukraine project П-3/22-2020.

\section{REFERENCES}

1. M. Dreval, C. Xiao, S. Elgriw, D. Trembach, S. Wolfe, A. Hirose. Determination of radial location of rotating magnetic islands by use of poloidal soft X-ray detector arrays in the STOR-M tokamak // Review of Scientific Instruments. 2011, v. 82, p. 053503.

2. M. Dreval, C. Xiao, A. Hirose. Numerical simulations of the soft X-ray signals for determination of radial locations of the magnetic islands in the STOR-M tokamak//
Radiation Effects and Defects in Solids. 2011, v. 166, p. 765 .

3. P. Franz, L. Marrelli, P. Piovesan, B. E. Chapman, P. Martin,

I. Predebon, G. Spizzo, R. B. White, C. Xiao. Observations of Multiple Magnetic Islands in the Core of a Reversed Field Pinch // Physical Review Letters. 2004, v. 92, p. 125001.

4. S. Morimoto, S. Okamoto, N. Yanagi, A. Iiyoshi, K. Uo. Effects of Light Impurities on Electron Temperature Measured by Soft X-Ray Filter Method // Japanese Journal of Applied Physics. 1986, v. 25, p. 120. 5. M. Dreval. Design and initial operation of multichord Soft X-ray detection array on the U-3M torsatron // Problems of Atomic Science and Technology. 2014, № 6, p. 250.

6. M. Dreval. First results of multichord soft x-ray detection array on the U-3M torsatron // Problems of Atomic Science and Technology. 2015, № 1, p. 8.

7. M. Dreval. Design of multichord soft x-ray detection arrays for the URAGAN-2M stellarator // Problems of Atomic Science and Technology. 2010, № 6, p. 11.

8. A.D. Komarov, A.A. Chmyga, V.V. Chechkin, L.I. Grigor'eva, G.N. Deshko, A.S. Kozachek, L.I. Krupnik, S.M. Khrebtov, S.M. Maznichenko, Yu.K. Mironov, V.S. Romanov, A.I. Zhezhera. Estimations of plasma potential and density by the heavy ion beam probing diagnostics on the URAGAN-2M torsatron // Problems of Atomic Science and Technology. 2016, № 6, p. 306.

9. O. Turianska, M. Dreval. Photodiodes spectral sensitivity influence on the two foils soft X-ray technique in the Uragan torsatrons // Bulletin Taras Shevchenko National University of Kyiv. 2017, v.1(25), p. 49.

Article received 07.10.2020

\section{ВЛИЯНИЕ СПЕКТРАЛЬНОЙ ЧУВСТВИТЕЛЬНОСТИ ФОТОДИОДА НА РАСЧЕТ ТЕМПЕРАТУРЫ ПО ДАННЫМ МЯГКОГО РЕНТГЕНОВСКОГО ИЗЛУЧЕНИЯ С ИСПОЛЬЗОВАНИЕМ ТОНКИХ ФИЛЬТРУЮЩИХ ФОЛЬГ НА УРАГАНЕ-ЗМ}

\section{Н.Б. Древаль, Е.В. Турянская, А.С. Пахур}

Диагностика плазмы на базе мягкого рентгеновского излучения постоянно используется на торсатроне Ураган-3М. Одним из диагностических приложений этой диагностики является оценка температуры плазмы. Соотношение сигналов мягкого рентгеновского излучения, прошедших через две разные фольги, зависит только от температуры плазмы и может использоваться для ее оценки. Численно рассмотрено влияние спектральной чувствительности фотодиода на методику оценки температуры плазмы методом двух фольг. В случае плоской спектральной чувствительности в диапазоне энергий 5...500 эВ и тонких $1,5 / 2,25$ мкм алюминиевых фольг это влияние незначительно. В случае очень низкой спектральной чувствительности в диапазоне $5 . . .500$ эВ и ее повышения в диапазоне 1 кэВ отношение сигналов, прошедших через две фольги, может быть очень высоким. Этот результат может объяснить высокое соотношение сигналов мягкого рентгеновского излучения, экспериментально наблюдаемое в стеллараторе Ураган-3М, где использовались фотодиоды с неизвестной спектральной чувствительностью.

\section{ВПЛИВ СПЕКТРАЛЬНОЇ ЧУТЛИВОСТІ ФОТОДІОДІВ НА РОЗРАХУНОК ТЕМПЕРАТУРИ ЗА ДАНИМИ М'ЯКОГО РЕНТГЕНІВСЬКОГО ВИПРОМІНЮВАННЯ 3 ВИКОРИСТАННЯМ ТОНКИХ ФІЛЬТРУЮЧИХ ФОЛЬГ НА УРАГАНІ-ЗМ М.Б. Древаль, О.В. Турянська, А.С. Пагур}

Діагностика плазми на базі м'якого рентгенівського випромінювання завжди використовується на торсатроні Ураган-3М. Одним з діагностичних застосувань цієї діагностики є оцінка температури плазми. Співвідношення сигналів м'якого рентгенівського випромінювання, що пройшли через дві різні фольги, залежить тільки від температури плазми і може використовуватися для ії оцінки. Чисельно розглянуто вплив спектральної чутливості фотодіода на методику оцінки температури плазми методом двох фольг. У випадку плоскої спектральної чутливості в діапазоні енергій $5 \ldots 500 \mathrm{eB}$ і тонких 1,5/2,25 мкм алюмінісвих фольги цей вплив незначний. У випадку дуже низькою спектральної чутливості в діапазоні $5 . .500 \mathrm{eB}$ і ії підвищення в діапазоні 1 кеВ співвідношення сигналів, що пройшли через дві фольги може бути дуже високим. Цей результат може пояснити високе співвідношення сигналів м'якого рентгенівського випромінювання, що експериментально спостерігалося в стелараторі Ураган-3М, де використовувалися фотодіоди з невідомою спектральною чутливістю. 